\title{
HUBUNGAN INTERAKSI IBU UAMII, DAN BIDAN, PENGETAHUAN, SIKAP IBU HAMIL, DENGAN KONSUMSI ASAM FOLAT UNTUK MENCEGAH CACAT [BAWAAN PADA BAYI DI KOTA MEDAN TAIIUN 2012
}

\author{
Bebaskita br Ginting', Elisabeth Surbakti ${ }^{2}$, Nurida Nasution ${ }^{3}$ \\ 'Dosen Tetaj Di Jurusan Kehidanan Medan \\ ${ }^{2}$ Dosen Tetan Di Jurusan Kebjidanan Medan \\ ${ }^{3}$ Dosen Tetap Di Program Studi Kebidanan P'xdang Sidempian
}

\begin{abstract}
Abstrak
Merencanakan kelamilan merupakan wakitu yang tcpal untuk mengadopsi perilaku untuk meningkatkan keschatan ibu hamil dan janin. Status nutrisi matemal berperan penting menentukan keluaran kehamilan. Persiapau untuk keschatan ibu hamil harus dimulai selama periode prekonsepsi dan sejak dini dalam masa kelamilan. bahkin sebelum ibu menyadari kehamilannya. Berbagai penelitian menemukan adanya risiko terjadinya caca janin apabila asupan asan folat kurang dari kecukupan. March of Dimcs Nationul tahun 1995 - 2001 melaporkan, asam folat mampu mencegah cacat bawan berupa cacat tabung syaraf atau Netural Tuhe Defect (NTD) pada bayi hingga $70 \%$.

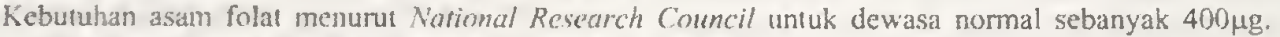
Perilaku konsumsi asam folat dapat dipengaruhi oleh sikap dan perilaku ibu dan interaksi yang berkailan dengan informasi kesehatan, dan pengalaman yang merubah perilaku. Menganalisis hubungan interaksi ibu hamil dengan bidan, pengetahuan dan sikap ibu hamil terhadap konsumsi asam folat untuk mencegah Cacat Bawaan pada bayi. Penelitian ini merupakan penelitian observasional dengan rancangan study crossectional. Subjek penelitian adalah Ibu hamil Primigravida yang usia kehamilannya trimester I yang melakukan pelayanan ANC di Klinik Bidan Delima Kola Medan. Pengambilan sampel dilakukan dengan purposive sumpling. terhadap 105 orang responden. Data diukur menggunakan kuesioner yang telah diuji validitas dan reliabilitasnya. Selanjutnya ciata ditnalisis secara univanat dengan tabel distribusi frekuensi, dilanjutkan secara bivariat menggunakan uji statistik Chi Squure dan secara multivariat menggunakan uji statistik regresi logistic. Sebanyak $61,90 \%$ ibu hamil berinteraksi baik dengan bidan, $57,38 \%$ memiliki pengetahuan baik; sebanyak $52.38 \%$ ibu hamil bersikap mendukung upaya pencegahan cacat bawaan pada bayi dan $52,4 \%$ ibu hamil memiliki praktek yang baik dalam konsumsi asam folat dalam upaya pencegahan cacat bawaan pada bayi. Interaksi ibu dengan bidan dan pengetahuan memiliki hubungan yang bermakna dengan praktek konsumsi asam folat masing masing dengan $p<0,01 ; R P 3,61$ (95\% Cl:1,91-6,84) untuk interaksi, $p<0,01: R P 2,19(95 \% \mathrm{Cl}: 1,37-3,50)$ untuk pengetahuan dan $p<0,05 ; R P 1,59(95 \% \mathrm{Cl}$ : 1.07-2.35). Praktek Konsumsi asam folat dalam upaya pencegahan cacat bawaan pada bayi lebih banyak terdapat pada ibu yang memiliki interaksi dengan bidan dan, pengetahuan yang baik dibandingkan dengan ibu hamil yang memiliki interaksi, dan pengetahuan yang kurang baik.
\end{abstract}

Kata Kunci : Interaksi, Pengetahuan, Sikap, Konsumsi asam folat, Cacat Bawaan

\section{Pendahuluan}

Status nutrisi matemal berperan penting menentukan keluaran kehamilan. Persiapan untuk kesehatan ibu hamil harus dimulai selama periode prekonsepsi dan sejak dini dalam masa kehamilan, bahkan sebelum kehamilan. Asupan berbagai zat gizi termasuk konsumsi asam folat harus terpenuhi karena sangat vital selsali fungsinya terulana mencegah terjadinya cacat janin.

Berbagai penelitian menemukan adanya risiko tegadinya cacat janin apabila asupan asam folat kurang dari kecukupan, bahkan cacat ini sudah muncul sebelum ibu menyadari dirinya hamil. March of Dimes National tahun 1995 - 2001, melaporkan asam folat mampu mencegah cacat bawaan berupa cacat tabung syaraf atau Neural Tube Defect (NTD) pada bayi hingga $70 \%$. NTD merupakan kelainan bawaan pada otak, tulang kepala dan sumsum tulang belakang yang disebabkan oleh gangguan pembentukan saluran saraf pusat pada masa organogenesis yaitu trimester pertama kehamilan terutama 28 hari postkonsepsi. Angka kejadian NTD berkisar antara 1,3 - 2 per 1000 bayi hidup terjadi di AS. 
Di Indmesia nemang belum ada data yanty pasti mengena jumial penderita NTD. Nanun setiap bulan. diri 300 ibu hanil yaug memeriksakan kehanilanilya di RSCM, 3 pasien diantaranya terbukti janinnya menderita NTD. Sebuah studi yang meneliti kejadian kelainan kongenital pada bayi bara lahir di RSU Kariadi Semarang menemukisn bahua kelainan berupa NTD merupakan kelainan kongenital terbanyak yang terjadi pada bayi ban lahir yaitu $47.2 \%$ dari selunil cacat congenital pada bayi banu lahir atau 3.7 per 1000 persalinan ${ }^{2}$.

Keburuhan asam folat menurut National Research Comncil untuk dewass nomal sebanyak $400 \mu \mathrm{g}$. Sedangkan kctutuhan minimum perharj adalah sekitas 50 $\mu g$, tetapi bagi wanita dianjurkan untuk mengkonsumsi sebanyak $400 \mu \mathrm{g}$ hari. Jumlah ini mampu mencegah risiko NTD scbanyak $50-70 \%$. Kebutuhan ini akan meningkat disaat hamil dan menyusui, minimum meningkat sebanyak $100 \mu \mathrm{g}$ /hari, tetapi dianjurkan berturut-turut sebanyak 600 $800 \mu \mathrm{g}$ /han ${ }^{3}$ atau $50 \%$ lebih banyak dibandingkan wanita yang tidak hamil. Bagi wanita hamil dan menyusui perlu meningkatkan konsumsi folat melalui makanan yang difortifiksi maupun dengan suplementasi asam folat.

Suplementasi asam folat menyebabkan terjadinya penurunan angka kejadian NTD dan pemberian asam folat antagonis menyebabkan terjadinya peningkatan angka kcjadian. Konsentrasi asam folat pada serum dan sel darah merah pada jbu hamil yang melahirkan anak dengan NTD lebih rendah dari ibu hamil yang melahirkar anak normal ${ }^{4}$. Beherapa hipotesis telah dikenukakan bahwa asam folat memfasilitasi kecepatan pentbelahan sel pada saat penutupan tabung neural. Kadar asam folat yang rendah menyebabkan kurang adekuatnya kecepatan pembelahan sel dan masalah ini bisa diselesaikan dengan pemberian suplementasi asam folat ${ }^{4}$.

Kekurangan asam folat dapat menyebabkan perkembangan sistem saraf utama terganggu pada janin, yang meliputi: Spina bifida yaitu adanya celah pada tulang belakang schingya tidak bisa tertutup sempuma akibat beberapa tulang yang gagal beraut (65\%), Anensefali yaitu tidak sempurnanya pertumbuhas tengkorak kepala dan otak. Jenis yang sering membawa kematian begitu bayi dilahirkan $(25 \%)$ dan Incephalocele vaitu adanya tonjolan di belakang kepala (10\%).

Selain itu kekurangan asam folat dapat mengakibatkan kclainan pada sistem hornon (pada anak perempuan, di saat dewasa kelak bisa tidak mengalami (gangguan bclajar) perkenbangan pusat kecerdasan notorik (mengalami selain itu, juga berakibat pada sistem tidak ada kontrol untuk buan, tidak bisa berjalan tegak), adanya gangun buang air besar maupun kecil senta berperan penting jantung. Pada ibu hamil asan folat apabila konsumsi a lam pembentukan sel darah merah mengalami ancmin megaloblastik ${ }^{5}$.

Perilaku konsumsi asam folat dapat dipengaruhi oleh sikap dan perilaku ibu dan interaksi yang berkaikan dengan informasi kesehatan, dan
pengalaman yang merubah perilakufi.
Penelifian bertujuan menganalisig interaksi bu hamil dan bidan, pengetahuan hamil dengan konsumsi asam folat untuk

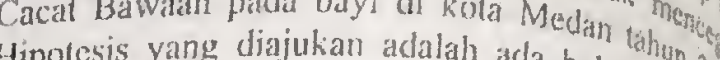
interaksi ibu hamil dongan bidan hum sikap ibu hamil dengan praktek ibu hatuan konsumsi asam folat unluk mencegah cacal pada bayi; ada pengaruh interaksi ibu hamil alk bidan ,pengetahuan dan sikap ibu hamil praktek ibu hamil dalam konsumsi asam folat un

\section{Metode Penelitian}

Penelitian ini merupakan penelitian observas. dengan rancangan cross-sectional, dilakukan di Kib Bersalin Bidan Delima di Kota Medan yang dijadilo lahan praktek mahasiswa Kebidanan yang terdiri dari Klinik bersalin dari 48 Klinik Bersalin Bidan Delima ya ada di Kota Medan pada bulan Juni sampai Agustus 2013 Populasi sasaran adalah ibu hamil yang memeriksaka kehamilan di Klinik Bersalin Bidan Delima Kota Medan dengan besar sampel sebanyak 105 orang menggunaka teknik purposive sampling yang terdiri dari ibu hami primigravida yang usia kehamilannya trimester pertanna 12 minggu). Alat ukur menggunakan kuesioner yang dikembangkan sesuai dengan teori pencegahan cicm tabung saraf. Kuesioner telah diuji validitasnt? menggunakan rumus korelasi product moment dan reabilitasnya menggunakan rumus koefisicn Alpha.

Selanjutnya analisis data dilakukan dengan analisis univariabel menggunakan distribusi frekuensi, analisis bivariabel menggunakan uji statistik chi-squars $\left(x^{2}\right)$, dengan tingkat kemaknaan $p<0.05$ dan $(95 \%$ C) serta Rasio prevalens dan analisis multivariabel menggunakan multiple logistic regression.

\section{Hasil Penelitian}

Karakteristik Responden Penelitian

\begin{tabular}{|c|c|c|}
\hline Karakteristik & $n=105$ & $\%$ \\
\hline umur & & \\
\hline $\begin{array}{l}20-<35 \\
<20 \&>35\end{array}$ & 100 & 95,24 \\
\hline $\begin{array}{l}<20 \& \geq 35 \\
\text { Tingkat Pendidikan }\end{array}$ & 5 & 4,76 \\
\hline Pendidikan Tinggi & 65 & 61,90 \\
\hline $\begin{array}{l}\text { Pendidikan Rendah } \\
\text { Status Bekerja }\end{array}$ & 40 & 38,10 \\
\hline $\begin{array}{l}\text { Bekerja diluar numah } \\
\text { Tidak bekerja diluar rumah }\end{array}$ & 29 & 27.62 \\
\hline & 76 & 72.38 \\
\hline
\end{tabular}

Berdasarkan Tabel 1. diatas terlihat bahwa reproduksi penelitian mayoritas berada pada usia yang tinggi (tamat $61,9 \%$ serta tidak beker'a dan Pergunian Tinggi) sebanyak 


\section{Prahteli Konsumid Asam lolat}

Total skor froktck honsunsis asom fold dihitung

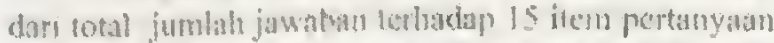
พৈng diherihan, selningga wal skor bovda di kisaran

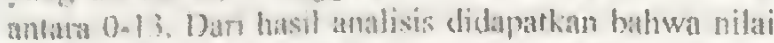
tertingui 15 sedanghan mat terendah alalah 0 dengan Ifodian 12

'Total skol Priktck Konsumsi Asam folat dilakuhan pengelompokan menjad data Ordinal. Schagat cut iff pomt yang diperguakan adabah median yaiu 12. sohingra skor 12 keatas masuk kategori Praklek Konsunsi Asam Folat yang baik dan skor <12 nasuk kategon Prahtek Konsumsi Asam Folat yang Kumng Bak. Dari hasil pengelomnokiar karlegori Praktek Konsumi asam folat young baik dan yang kurang baik maka didapatkan hasil sehagii berikut

Tabet 2. Distrihusi Jrekuensi Kesponden Berdasarkan Praktck Konsumsi Asam liolat

\begin{tabular}{|c|c|c|}
\hline Prakteh Kinnsumsi Asam. Folat & Jumlah (n) & $\%$ \\
\hline Baik & 55 & 52,4 \\
\hline Kurang lask & 50 & 47.0 \\
\hline Torta! & 105 & 100 \\
\hline
\end{tabular}

Herdasartan tahel. 2 diatas dapat dilihat bahwa mayorias wpom Jen $\left(52,4^{\circ}\right.$ ) melakukan piaklek yang baik dalan upaya pencegihan cacat bawan pada buyi dengan t. ns:

\section{Interahsi Bidan deman lbu Hamil}

Total sho" interaksi Bidan dengan thu Hanil dalan k7:us ne? cegahar cacat bawaan dengan asam folat dihimug dai total jumlah jawaban responden terhadar is pertanyan yang diberikan, sehingga total skor berada di kivran antara 0-6. Dari husil analisis didupatkan batwn nilai tertinggi 6 sedangkan nilai terendah adalah 1) dejgan Modian 6. Total skor Interaksi Budan dengan Ibu Hani! dilakukin pengelompokan nenjadi data ordinal. Scbagai cul off point yang dipergunakan adalah nilai maksimal, sehingga skor 6 keatas masuk kategori baik dan $<6$ masuk kategori kurang baik. Dari hasil pengelompokan kategori Interaksi Bidan dengan Ibu Hamil yang baik dan yang kurang baik maka didapatkan hasil sebagai berikut :

Tahel 3. Distribusi Frekuensi Responden Berdasarkan Juteraksi dengan Bidan

\begin{tabular}{|c|c|c|}
\hline Interaksi dengan Bidan & Jumlah (n) & $\%$ \\
\hline Baik & 65 & 61,90 \\
\hline Kurany Baik & 40 & 38,10 \\
\hline Total & 105 & 100 \\
\hline
\end{tabular}

Berdasarkan tahel.3 diatas dapat dilihat bahwa mayoritas responden $(61,90 \%)$ memiliki interaksi yang baik dengan bidan dalam upaya pencegahan cacat bawaan pada bayi dengan konsumsi asam folat.
Pengetahuan Ihu Hamil Tentang Ijpatya Pencezahan Cucat Hawann l'adu bayl.

folal skor nengetahum itw hamil fentarga konsumsi usann folat dihitung diri total jumlah jawaban yang benat torhatap 26 item peranyann yong diberikan. schingea total skor bertua di kisatan antar a 0-26. Dari hasil analisıs didapatkan bahwa nilai tertinggi 24 sedangkan nilai terendah adalah 8 dengan Median 18

Toul skor pengetahuan Itu Hamil dilakukan pengclompokan menjadı datu Ordiral. Sebagai cat off prim yang dipcrgunakan alalah median yaitu 18 , sehingga skor 18 kcalus masuk kategori baik dan 17 kchawah masuk kalegori kurang baik. Dari hasil pengelompnkan kategori pengctahuan tentang asam fulat yang baik dan yang kurang baik maka didapatkan lasil sebagai berikut :

T'abel 4. Distrihusi l'rekucnsi Responden Berdasurkay Pengetahusn Ientang Konsumsi Asam folat

J'engctahuan tentasg Komsumsifumbah (n) \%

Asan Folat

\begin{tabular}{|c|c|c|}
\hline Baik & 60 & 57.38 \\
\hline Kurang Bitik & 45 & 42.62 \\
\hline Total & 105 & 100 \\
\hline
\end{tabular}

Berdasarkan tabel. 7 diatas aypat dilihat bahwa

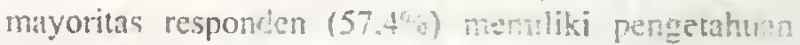
yang bilik tentang konsumst asam "olvt.

Sikap Ibu llamil tentane linnsums! Asam Folat

Total sko's pengetahum its haalit tentang konsumsi usam tobll distung thrt torai junith jawaban yang berar terhat ap 14 iter pertanyan yong diberikan, schingea total skor nerudi di kisarun artura 0-42. Dari hasil analisis Jidapathan buhua nilai tertinggi 40 sedangh an nilai terendio adalah 21 dengun Median 33

Total stior sikap lbu Hamil dilakukan pengelompokan menjadi dasa Ordinal. Sebagni cu off point yang dipergunakan adalah metian yaitu 33, sehingga skor 33 keatas masuk kategori Sikap Positif dan skor <33 masuk kateguri sikap negatif. Dori hasil pengelompokan kategori Sikap lbu Hamil tentang Konsumsi asam folat yang positif dan negatif maki didapatkan hasil sebagai borikut :

'Tabel 5. Distribusi Frekuensi Responden Berdasarkan Sikap dalam Pemberian Asam Folat

\begin{tabular}{lccc}
\multicolumn{2}{c}{ Sikap Ibu Hamil } & Jumlah (n) & $\%$ \\
\hline Positif & Total & 55 & 52,38 \\
Negatif & 50 & 47,62 \\
\hline & To5 & 100 \\
\hline
\end{tabular}

Berdasarkan tabel.5 diatas dapal dilihat. bahwa mayoritas responden $(52,38 \%)$ memiliki sikap positif upaya pencegahan cacat bawaan pada bayi deugan konsumsi asam folat. 


\section{Analkis Rivaria!}

Analinis hivariabel sigunakan untuk melihat Inulungass wariabel teprenden dengan variahel undepluten menggunakan uji rhi-square dan Ratio Brovlence/1RP". Pengujian hipotesis penefitian didesarkan ntas faraf signilikansi $5 \%(P=0.05)$ din Cimfitemer Interval (Cl) 95\%.

Hubungan Intcraksi Bidan, Pengetahuan dan Sikan thu Hamil dengan Praktek Konsumsi Asam Folat scilla lebih jelas dapall dilihan dalan tabel 6. Berikut ini:

Tabel 6. Huhungan Karakferistik responden, Intcrahsi Bidan, Jengetahuan dan Sikap lhu Hamil dengan Praktek Konsumsi Asam Folat di Kota l'raktek Konsumsi Asam folat di Kota Medan tahun 2012

Variabel Prakick Konsumsi

$\frac{\text { Asam Folat }}{\text { Baik Kuran \% }} \quad P \quad$ RP Cl95\%

Timur g Baik

$\begin{array}{cccccc}20-535 & 54 & 46 & 0,19 & 0,37 & 0,06.2,15 \\ 20-735 & 1 & 4 & & & \end{array}$

\section{Tht}

Tendidikan

Tingei

Romilah 32

$\begin{array}{ll}32 & 32 \\ 22 & 18\end{array}$

32
18

$0.69 \quad 1.08$

Starus

herja

Diliar runah 16

Tivak heheria 34

dituar rusuah

13

37

$0,83 \quad 1,08 \quad 0,73-1,59$

Intcrakisi

Biaik

hirang Baik

$47 \quad 44,76$

$\begin{array}{lllll}8 & 7.62 & 18 & 17,14 & 0.00 * * \\ 32 & 30,48\end{array}$

$1,91-6,84$

\section{Pengetahuan}

Baik

Kurang Baik 4149,05 14 18,10

Sikap

Posilif

\begin{tabular}{lrrrr} 
Negatif $\quad 20$ & 19.05 & 20 & 19,05 \\
\hline Ket: ${ }^{*}=<0,05 ; ;^{* *}=<0,01$ & 30 & 28,57
\end{tabular}

Berdasarkan analisis pada tabel 6. diketahui bahwa Interaksj Bidan dengan ibu hamil, pengetahuan ibu hamil dan sikup ibu hamil memiliki hubungan bennakna dengan praktek konsumsi asam folat. Variabel interaksi ibu hami] artinya responden yang meniliki (Cl 95\%:1,91-6,84) dengan bidan memiliki kemungiki interaksi yang baik melakukan praktek konsuminkinan sebanyak 3,61 kali dibandingkan dengan respond asam folat yang baik yang kurang baik dengas bidan yang memiliki interaksi hamil dengan $p<0,01$. Rp artinya ibu hamil yang memiliki pengetahu 1 (CI 95\%:1,37-3,50) tentang upaya pencegahan inemiliki pengetahuan yang baik memiliki kemungkinan 2,19 kali lebih bawaan pada bayi praklek konsumsi iısm dengan responden yang memiliki pengetahuan yang kurang baik. Varieabel sikap ibu hami $P=0,05, R P^{2}=1,59 \quad(C / 95 \%: 1,07.2,35)$ anil detrigat bawan pada bayi memiliki kem lipaya penca

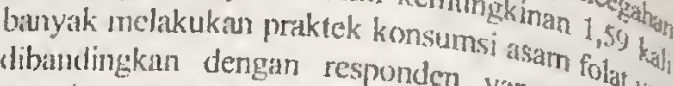
dibaudingkan dengan responden yang memil yas negative. Sedangknn variabel umur ibu hamil, derm status bekerja ibu hamil, tidak menunjuk, phan dengan praktek konsumsi memiliki nilai $p>0,05$.

\section{Analisis Multivariat}

Puda penelitian ini, variabel memenuhi kriteria $p<0,25$ pad independe dimasukkan ke dalam analisis analisis menggunakan uji regresi logistik berivarial bivarig mendapatkan faktor yang paling dominanganda, diuji secara bersana-sama dengan men, scmuak kandid cner: Fakitor yang tcrbaik akin dipertimbunakan metolk melihat nilai p. Pada setiap tahapon seleksi vkan denger lidak signifikan $(\gamma>0,05)$ dikcluarkan satu perrabl yalig dari $p$ yang terbesis. Setiap tahapan seleksi dilakukan dengan cara yang sama hingeleksi sclarjuthm diperoleh variabel yang seluruhnya berhubungan seleksikhis $(p<0.05)$.

Padu metode dalam analis yaitu enter tahap pertama yang dithukas hamil dengan bidiu variabel umur ibu hamil, interaksi ing sikap ibu hamil dallam unaya pengetahuan vidn variahel pada bayi.Hasilnya interaksi pencegahan cacat bawas pengetahuan ibu hamil memiliki hubull dan bidan, dan dengan prakıck konsumsi a huburgan yang benmakna $p<0,01 ; \operatorname{Eip}(B): 0,14\left(05^{n}, \mathrm{C}\right.$. interaksi ibu hanil Jengan bit: $0.05-0,39)$ unnk tariabe? nilai 1) aninyn variabel proteksi praktck yang kurang yang meegah ibu hamil melakukan hamil memiliki kemungkinan konsumsi asam folat. Ibu melakukan pruktek konsunginan sebanyak 0,14 kali dibandingkan variabel Cl: $0,13-0.90)$ untuk lain dan $p<0,05 ; \operatorname{Erp}(B): 0,34(95 \%$ 95\% tidak mencakup variabel pengetahuan ibu hamil (C) hamil merupakan variabel 1) artinya pengetahuan ibu hamil melakukan praktek yansi yang mencegah ibu konsumsi asam praktek yang kurang baik dalan sebanyak 0,34 kalat. Ibu hamil memiliki kemungkinan folat yang kurang melakukan praktek konsumsi asam Variabel unnur ibu baik dibandingkan variabel lain. memiliki hubungan hamil dan sikap ibu hamil tidak konsumsi asam folat kareng bermakna clengan praktck Selanjutnya dilak nilai $p>0,05$.

enter tahap kedua dilakukan analisis dengan metode variabel unur ibu yang bertujuan menganalis hubungan variabel pengetahuan ibu interaksi ibu hamil dengan bidan, dengan praklek konsums hamil secara bersama-sama ibu hamil dan bidan, dan pengen folat. Hasilnya interaksi hubungan yang bernakna pengetahuan ibu hamil memiliki folat, masing dengan $p<0,0$, $0,36)$ untuk variabel interaki $\mathrm{p}^{<0,01 ;} \operatorname{Exp}(B): 0,13(95 \% \mathrm{Cl}: 0,05-$ 95\% tidak mencakup nilai ibu hamil dengan bidan ( $\mathrm{CI}$ 


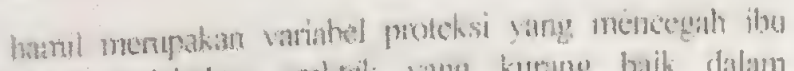
hami melakikm poukeck ving kuramy baik dalam

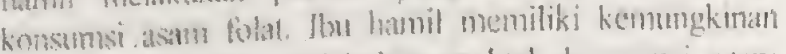

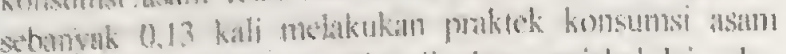
forar smug humng bath dilvindingkin variabol lain dam

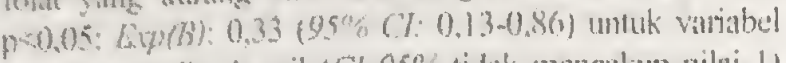
pengetuhuan ibu bannil (C) $95 \%$ tidith mencakup nilai 1) artinya pengetsluan ibu lamil merupakan variabel proteksi yaug mencegah ilu hamil melativkan praktek yang kurang baik dalan honsumsi asum folla. Ibu hamil memiliki kemunghinan scbanyak 0,33 kali molakukan praklek konsunn asam folat yang kuming baik dibandingkan vaniabed lain. Varabel umur ibu hamil tidak memiliki hubungan bemakna dengan praklek konsumsi asam folat karens nilai $p>0,05$.

Sclanjumya dilakukan analisis metode enter talkap ketigat yang hanya mengikutkitn variabel independen yang memiliki nilai $p<0.05$ pada tahup sebelumnya yaritu varicabel ineraksi ibu hamil dengan bidan dan variabel pengetahuan ibu hamil. Hasilnya terlihat pada lable berikut:

Tabel 7. Analisis Multivariabel antara Interaksi Ibu Hamil dan Bidan, Pengengetahuan Ibu Hamil dengan Praktck Konsumsi Asan Folat

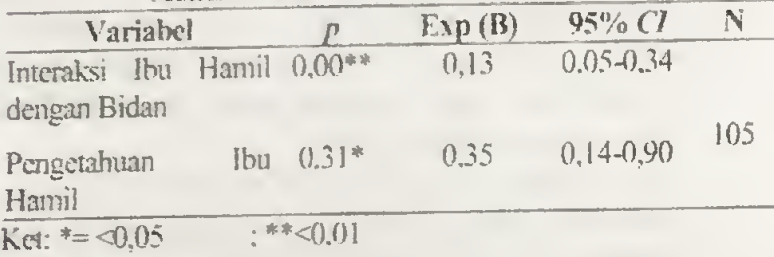

Dari hasil seleksi terakhir menunjukkan bahw'a inieraksi ibu hamil dengan bidan dan pengetahuan ibu hanil memiliki hubungan yang bermakna dengan praktek konsumsi asam folat. Berdasarkan nilai koefisien dapat dilihat hahwa variabel Interaksi "Ibu Hamil dengan Bidan merupakan variabel yang paling dominan berpenguruh dengan praktek konsumsi asam folat. Besar hubungan variabel tersebut dapat dilihat dari rasio prevalensi sebesar 0,13 dengan $95 \% \mathrm{Cl}: 0,05-0,34$ (ridak mencakup angka 1) artinya responden yang memiliki interaksi yang baik dengan bidan justru merupakan factor protektif yang mencegah ibu memiliki praktek yang kurang baik clalam konsumsi asam folat. Responden yang memiliki interaksi yang baik dengan bidan memiliki resiko melakukan praktek konsumsi asam folat yang kurang baik 0,13 kali dibandingkan dengan responden yang memiliki interaksi yang kurang baik ${ }^{\circ}$.

\section{Pembahasan}

\section{Praktek Konsumsi Asam Folat}

Hasil analisa data memperlihatkan bahwa meskipun mayoritas responden suclah mempraktekkan konsumsi asam folat dengan baik $(52,6 \%)$, namun sebanyak $47,6 \%$ ibu hamil belum mempraktekkan konsumsi asam folat dengan baik.

Selama ini asan folat lebih dikenal sehagai tambahan atau suplementasi dalam susu. Namun sebenarnya asim folat sendiri secara alami terkandung

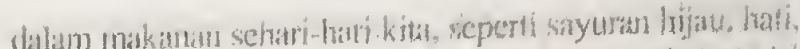
daging, kacang biji, clam sehagarna. Mcnurut tabel nalrisi makanan Inchuksia, kandungan asam folat yang dingeg

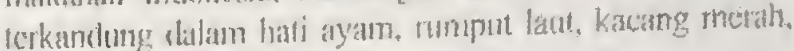
dan kacang kedelai.

Ju lamil sebaiknya mengonsumsi akam folat setidaknya $40(1)$ flg perhari. Jui juga menplokan cara tantuk menckan risiko kcliinan labung syant N'TT)s (newrul tube defects) hingga 70 persen kelahiran. Kelainan sejak lahir ini tcrmasilk ketidaksempurnatan perkembangan otak (ansycephaly') dan tulang belakang atau syma hifida?

Unfuk memenuhi angka ini, tidak harus dengan suplementasi (tablet). Nanjun dari makanan sehari-hari juga bisa memenuhi kebutuhan asam folat, lanya tinggal mengganti beberapa lauk atau pilihan bahan makanan yang kaya asim folat.

Masih banyaknya ibu hamil yang belum mempraktckkan mengkonsumsi asam folat dengan baik akin meningkatkan resiko keluaran kchamilan yang kurang baik. Seperti dikctahui bahwa Asam Folat merupakan Finzin yang memproduksi DNA (Deoxyribose Nuclcic Acid), membantu pembclahan sel, mencegah Anemia dan menurunkan resiko terjadinya NTD (Neural Tube Effects). Asam folat juga sangat penting karena sifatnya menghanbat secara signifikan zat teratogenik / pengganggu pembentukan sel jaringan janin, ini dapat menckan kelainan pada janin terutama di perjode pembentukan janin padá masa kehamilan.

Meski tak bisa dikatakan sebagai satu-satunya pencegah kecacatan janin, namun paling tidak asam folat mampu merecluksi efek zat-zal yang merusak atau menghambat pertumbuhan janin seperti radikal bebas, zat artifisial yang tidak aman. racun dan polutan. Tanpa adanya asam folat, zat-zat teratogenik semakin tak terbendung merusak dan mengganggu proses dalam inti sel-sel yang sedang bertumbuh. Dengan kata lain kalau zat yang mereduksi efek teratogenik kurang, maka kensakan yang ditimbulkan akan semakin bunk

\section{Interaksi Bidau dengan lbu Hamil}

Data pada table 3 memperlihatkan bahwa sebanyak $61,90 \%$ responden dalam penelitian ini memiliki interaksi yang baik dengan bidan dalam upaya pencegahan cacat bawaan pada bayi dengan konsumsi asam folat. Pada analisis bivariat juga terlihat bahwa interaksi ibu hamil dengan bidan memiliki hubungan bermakna dengan praktek konsumsi asam folat dengan nilai $p<0,01$; RP 3,61 (95\% Cl: 1,916,84 ), yang artinya ibu hamil yang memiliki interaksi yang baik dengan bidan dalam upaya pencegahan cacat bawaan pada bayi memiliki kemungkinan 3,61 kali lebih banyak melakukan praktek yang baik dalam konsumsi asam folat dibandingkan dengan ibu hamil yang memiliki interaksi yang kurang baik dengan bidan.

Hasil penelitian ini mendukung pemyataan Notoatmodjo, 2007 yang mengatakan balma Perilaku dalam bentuk praktek seseorang sangat dipengaruhi olch pengetahuan yang diperoleh dari berbagai sumber, antara lain lewat petugas kesehatan? 


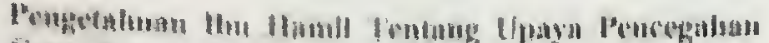

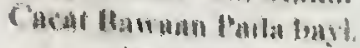

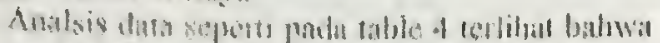

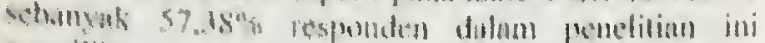

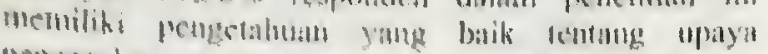

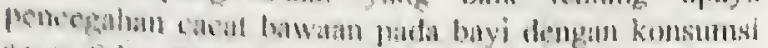

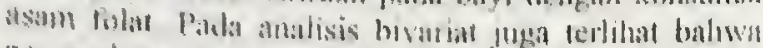
pongerahuan ilu fiomit menuiliki hubungan hermakna dongan praktek honstumsi asam folat dengan nilai $\rho$

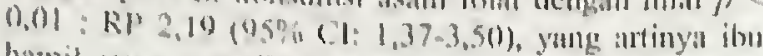
hamil yang mesnilihi pengetshuan yang haik dalam

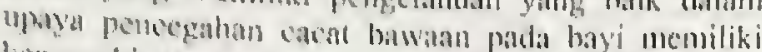
ksmumghinan 2.10 knli lebih banyak melakukan makel yang baik dilam konsumsi asam folat dibandingkan dengan ilu hamil yang memiliki pengetaluan yang kitamg bash.

l'engetaluan menurni Gren merupukon silith soru baktor yong menjisti dasir / motivasi untuk bertindak

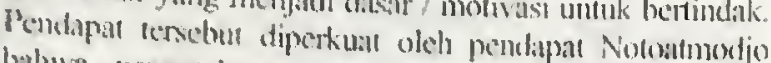

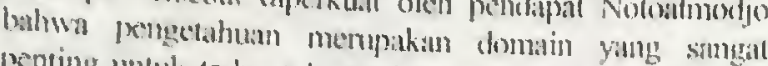
penting untuk tetbonfuknya tindakan (praktek) scseoring, dan prakkek akan bersifat langueng apabila didasuri oleh pengetaliuan yang positifn"

\section{Sihop thu Hamil Tentang housumsi Asau Folat}

Meskjum sebanyak $52,38 \%$ respunden dalam penelibar ini moraliki sikap yang posistif tontang "praya penceguhan cacal bawasn pada bayi dengan hanvunsi jsalm folam namun masil ada $47,2 \%$ responden yang meiliki sikap yatmg negulif tentang Hpryy pencegalian cacat bawaan pada nityi dengan homsunsi asam folu. Pata analisis bivarial juga terlihat bahua sikap ibu hamil memilikj hubungan bematina dengan praktek konsumsi asam folat dengan nilai $p$ $0.05: R P^{P} 1.59(95 \% \mathrm{Cl}: 1.07-2,35)$, yang arlinya ibu hamil yang memiliki sikap yang bajk dalam upaya kencegahan cacar bawan pada bayi memiliki praktek vang baik kali lebih banyak melakukan dihandingkan bak dala!n konsumsi asam folat yang kurang baik. Namumil yang memiliki sikap dengan regresi logistic vamun dalam uji multivariate memiliki hubungin variabel sikap ibu hamil tidak konsumsi asam folat bernakna dengan praktek Hasil pem torena nilai $p>0,05$.

Notoadmodjo bahwalian ini didukung oleh pernyataan dalam bentuk praktek. Untuk belum otomatis terwujud menjadi perbuatan nyata pendukung atau kondisi (praktek) diperlukan faktor merupakan reaksi atiu resin yang memungkinkan. Sikap seseorang terhadap suatu stimulus atau masih tertutup dari merupakan suatu tindakan atau aktifita objek. Sikap belum merupakan predisposisi tindak aktifitas, akan tetapi adalah Azwar $S^{9}$, sikap menbuat seseom atau perilaku ${ }^{6}$. Menurut menjauhi sesuatu. Sikap akan dikng untuk mendekat dan tindakan berdasarkan akan dikuti atau tidak oleh suatu pengalaman sescomang. palda sedikit atsu banyaknya

\section{Keximpulan}

1. Cimmbiran tomum praktek komsumej ditalu pencegalian cecal bowaan asam hak denginu bidan, $57,38 \%$ memil hering ba

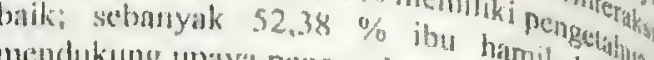
mendukung wpilya nenceguhan cacat baw bengik hayi dan $52.4 \%$ ibu hamil mcnilik praktek pal pencegahan cacal bawan folat daban yat Medan

2. Ada hubungan yang bermakna ibu hamil dan bidan clesggan antara interék asam folat dilam upaya peneegahan cacat kon pacla bayi di Kota Medan $(j<0,01 ; R)^{3} 3,61(09$ a
$C(: 1.9)-0.84)$ )

3. Ada hubungan pengetaluan ibu dengan praktek konsumsi asta di Kola Meclan $\left(0<0,01: R \gamma^{2}, 10\right.$,as pada bay $3,50)$ )

4. Acla hubumgan yang hormakma deıgan praktck konsumsi a antara sikap ibu pencogahan cucat bavan asam folat dalam

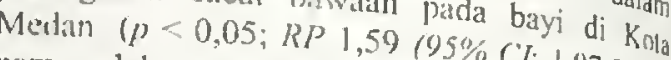
mamun dalam analisis mult $\%$ C\%: $1,07-2,35$ ticlak nımiliki hubungan heriabel sikap praktek konsumsi asam folat dakna denga pencegahan cacist bowarn folat daim upay Medan karena nilai p-0,05. pada bayj di Kola

5. Interaksi dan pengetahua

bermakna lonyan dala!n upay:i goncegahen cal di Fón Medan. Da cacat bawari pada bay paling berpengaruh kedua faktor tersubut yong (B) $=0,13$; y5 $C$ (Exp

Saran

1. Bagi Dinas Kesehatan

Dalam inclaksanakan program pencegahan cacal bawaan pada bilyi, khususnya kecacatan yung berhubungan dengan defisiensi asam folat, faktor interaksi ibu hamil dengan bidan dan pengetahuan ibu hamil untuk mendapatkan perhatian mengingat interaksi dengan bidan dan pengetahuan ibu pengaruhnya sangal besar terhadap praktek ibu dalam konsumsj asam folat

\section{Bagi Bidan}

a. Bagi Bidan di Pelayanan perlu menjaga kualitas komunikasi yang baik dengan ibu hamil, karena interaksi bidan berpengarub terhadap pengetahuan ibu hamil yang mempengaruhi perilakunya melakukan praktek konsumsi asain folat.

b. Bidan perlu meningkatkan pengetahuan dan memotifasi sikap serta praktek ibu hamil tentang: gizi makanan yang menbantu dan menghambat pembentukan zat besi yang dapat.mencegat terjadinya cacat bawaan pada bayi. 


\section{Daftar Pustaka}

Ameriom Cothege of Obsterricuns and Gyntcolngists

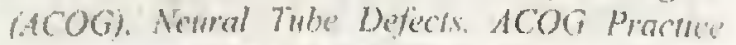

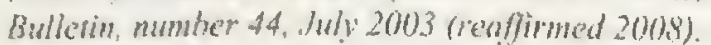

Prabawa, M., 1098. Kejadian Bayi Luhir dengan Kelainan Kongenilul. Fakultas Kedokteran Universiras Diponegoro Scmarang

Muchadi D, 1993. Metabolisme Zat Gizi, Pustaka Sinar Harapan, Jakarti. 151-15\%.

Honein MA, Paulczi LJ. Mathews TJ, Erickson J, Wong 1.C. 2001. Impact of Folic Acid fortification of the US rood Supply on the Occurrence of Neural Tube Defects. JAMA.;285(23):2981-2986
Almutsier, S. 2001. Prinsiy Basar IImu Gizi, Jakarta: Gramedia Pustaka Utama.

Noloammodjo Soekidjo, 2007. Prosnusi Keschatan dan llmu l'erilaku ( Edisi Revisi). Rincka Cipla

Ahren and f'igeot, 2000. Handbouk of Epidemiology. springer.

Ghazali, MV, dkk, 2011. Studi Cross-5ectional, Editor: Sastroasnoro, S., dan Ismacl, S., Edisi ke-4. Jakarta: Sagung Scio

Azwar, S., 2011. Sikap Manusia, Teori dan Pengukurannya (Edisi 2). Pustaka Pelajar, Yogyakaria. 